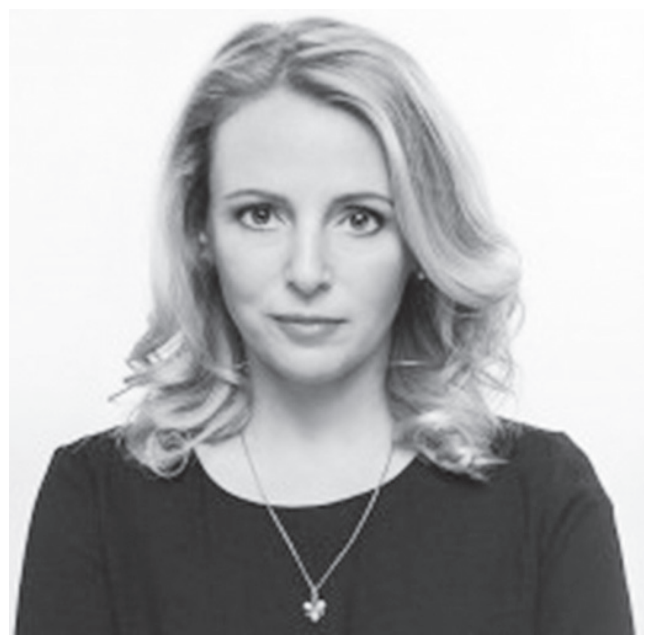

Юзвкова Елена Ивановна, аспирантка, Таврийский национальный университет по специильности "Государственное управление”, 02068, г. Киев, ул. Драгоманова, 316, тел.: (099) 07946 80, е-таil: e.yuzkova@gmail.com
UDC: 330.341.1:351

DOI: https://doi.org/10.32689/2617-

2224-2019-4(19)-310-321

\section{Yuzkova Olena Ivanivna,}

PhD Candidate, Tavriyskiy National University, specialization "Public Management", 02068, Kyiv, Dragomanova Str., 31B, tel.: (099) 07946 80, e-mail: e.yuzkova@gmail. com

ORCID: 0000-0002-0344-9693

Юзькова Олена Іванівна,

аспірантка, Таврійський національний університет за спеціальністю "Державне управління", 02068, м. Київ, вул. Драгоманова, 316, тел.: (099) 07946 80, e-mail: e.yuzkova@gmail.com

ORCID: 0000-0002-0344-9693

\title{
INNOVATION LEADERSHIP AS A FORM OF PROFESSIONAL EVOLUTION IN PUBLIC ADMINISTRATION
}

Abstract. Problematic issues of innovation leadership mechanisms implementation in government bodies in Ukraine during social changes attract more and more attention of researchers from different scientific fields. This process has several basic determinations which are represented in comparison built upon research results of innovative leader behaviour in organization based on organizational experience. The article provides comparative analysis of vision of an innovative leader made by representatives of public authorities as well as business representatives in relation with personal characteristics and behaviour model inside the organization in order to find out common factors as for innovation leadership forming as a professional evolution method in public administration and business environment. The article presents the research of conceptual construct as well as methodological aspects of innovation leadership based on cognitions discovery as for innovation leadership vision in organizational management, in particular in public management. The research is focused on depth of understanding such phenomenon as innovation leadership (not width as in quantitative/mass re- 
search) - i.e. detailed deep research and understanding of innovation leadership in its integrity and direct connection with other phenomena.

It is noted that that the business is always the first to introduce new ideas and concepts, and the public sector and government organizations take on the experience. Now, due to the requirements of the environment, the business is looking for new answers to the old questions: what is leadership? Which organization will be effective? And now we see how the companies introduce a new culture that promotes innovation, creativity, allows you to experiment, and share the groundwork, and become an example for the others. The most important challenge today is to create a culture of responsibility in which the decisions and proposals come not from an authoritative person, a representative of the power, but from people at all the levels.

Keywords: innovation leadership, innovation leadership in public administration, public management, innovation leadership development.

\section{ІННОВАЦІЙНЕ ЛІДЕРСТВО ЯК ФОРМА ПРОФЕСІЙНОЇ ЕВОЛЮЦІї В ДЕРЖАВНОМУ УПРАВЛІННІ}

Анотація. Проблемні питання впровадження механізмів інноваційного лідерства в діяльність органів державної влади в Україні в умовах суспільних змін привертають все більше уваги дослідників різних наукових напрямів. Цей процес має кілька базисних детермінантів, які представлені у порівнянні за результатами дослідження поведінки інноваційного лідера в організації на засадах організаційного досвіду. У статті також надано порівняльний аналіз бачення інноваційного лідера представниками органів державної влади та представниками бізнесу з точки зору особистісних характеристик та поведінкової моделі всередині організації з метою виявлення закономірностей до формування інноваційного лідерства як форми професійної еволюції у сфері державного управління та в бізнес-середовищі. У статті представлене дослідження понятійного та методичного аспектів інноваційного лідерства на основі виявлення когніцій щодо бачення інноваційного лідерства в управлінні організаціями, зокрема в державному управлінні. Дослідження орієнтоване на глибину розуміння такого явища як інноваційне лідерство (а не ширину як в кількісному/масовому дослідженні), тобто детальним, глибинним вивченням і розумінням інноваційного лідерства в його цілісності і безпосередньому взаємозв'язку з іншими явищами.

Відзначено, що бізнес завжди першим впроваджує нові ідеї та концепції, а громадський сектор та державні організації переймають досвід. Наразі, у зв'язку з вимогами зовнішнього середовища, бізнес шукає нові відповіді на старі питання: що таке лідерство? Яка організація буде ефективною? I зараз ми бачимо, як компанії впроваджують нову культуру, що сприяє інноваціям, творчості, дозволяє експериментувати, і діляться напрацюваннями, стають прикладом для інших. Чи не найголовніший виклик сьогодення - створювати культуру відповідальності, у якій рішення та пропозиції надходять не від авторитетної особи, представника влади, а від людей на усіх рівнях. 
Ключові слова: інноваційне лідерство, інноваційне лідерство в державному управлінні, державне управління, розвиток інноваційного лідерства.

\section{ИННОВАЦИОННОЕ ЛИДЕРСТВО КАК ФОРМА ПРОФЕССИОНАЛЬНОЙ ЭВОЛЮЦИИ В ГОСУДАРСТВЕННОМ УПРАВЛЕНИИ}

Аннотация. Проблемные вопросы внедрения механизмов инновационного лидерства в деятельность органов государственной власти в Украине в условиях социальных изменений привлекают все больше внимания исследователей различных научных направлений. Этот процесс имеет несколько базисных детерминантов, которые представлены в сравнении по результатам исследования поведения инновационного лидера в организации на основе организационного опыта. В статье также представлен сравнительный анализ видения инновационного лидера представителями органов государственной власти и представителями бизнеса с точки зрения личностных характеристик и поведенческой модели внутри организации с целью выявления закономерностей к формированию инновационного лидерства как формы профессиональной эволюции в сфере государственного управления и в бизнес-среде. В статье представлено исследование понятийного и методического аспектов инновационного лидерства на основе выявления когниций касательно видения инновационного лидерства в управлении организациями, в частности в государственном управлении. Исследование ориентировано на глубину понимания такого явления как инновационное лидерство (а не на ширину, как в количественном/массовом исследовании), то есть детальным глубинным изучением и пониманием инновационного лидерства в его целостности и непосредственной взаимосвязи с другими явлениями.

Отмечено, что бизнес всегда первым внедряет новые идеи и концепции, а общественный сектор и государственные организации перенимают опыт. Сейчас в связи с требованиями внешней среды, бизнес ищет новые ответы на старые вопросы: что такое лидерство? Какая организация будет эффективной? И сейчас мы видим, как компании внедряют новую культуру, которая способствует инновациям, творчеству, позволяет экспериментировать, и делятся наработками, становятся примером для других. Не самый ли главный вызов нашего времени - создавать культуру ответственности, в которой решения и предложения поступают не от авторитетного лица, представителя власти, а от людей на всех уровнях.

Ключевые слова: инновационное лидерство, инновационное лидерство в государственном управлении, государственное управление, развитие инновационного лидерства.

Formulation of the problem. The problem of the situation is that, in spite of the fact that the theoretical interests of the society, the organization 
and personality in providing favourable conditions for innovation leadership coincide, in practice there are obvious contradictions between their requests in relation to the leadership and the possibilities of the organization in the data of socio-economic and management conditions to realize the potential of the innovative leadership of their employees. In most organizations this difference reaches critical values and generates serious preconditions for socio-psychological and economic problems. Over the past few decades the leadership ideas have changed substantially, as well as the expectations from the leader. There were factors that greatly complicated our understanding of the world and its rules, namely:

- technology development;

- border blurring, development of the global economy;

- migration of the population;

- struggle for resources.

In this way, it was necessary to appear at the state level not just leaders, but innovative leaders.

A modern innovation leader is a change agent on the local and global levels. This does not mean controlling the processes from the beginning to the end, sometimes it is enough to show the path, attract, and others will pick up and scale the results. Therefore, everyone can be a leader - agent of the change - at his own level.

An analysis of the recent research and publications that launched the solution to this problem. There is currently no single opinion among the scholars regarding the identification of the mechanisms for sustainable leadership development and the improvement of the effectiveness and efficiency of these mechanisms. In the studying of the issues of leadership in the system of the public administration are engaged Ye. Abashkina, B. Kukhta, M. Logunova, V. Mishchyshyn, L. Pashko and others. Significant contribution to the research on the efficiency of the public administration was made by V. Averyanov, V. Bakumenko, A. Melnyk and others.

Formulation of the task. The purpose of the article is to study the conceptual and methodical aspects of the innovation leadership as a form of professional evolution based on the identification of cognition in terms of innovation leadership in the management of organizations, in particular, in public administration.

The subject of the research was the innovative leadership in the management of organizations.

The purpose of the research was to identify (diagnose) cognition (thoughts, rational behaviour) that arise from respondents (representatives of the state authorities and business representatives) when analyzing the behaviour of an innovative leader in an organization based on the organizational experience of the respondents.

\section{Presentation of the main material.} The level of the institutional changes in any area of the public administration is determined by the effectiveness of the implementation of the administration system by the relevant state institutions. Today it is necessary to solve the problems of improving the governance system in the state institutions in order to ensure the effectiveness and efficiency of the performance of the respective functions and services [1]. 
In this article the author proposes the results of the research of some parameters of the innovative leadership, individual and social, which is identified today with management. The first is related to the actualization of the needs of the people in securing their own safety and well-being in a changing and rapidly developing environment of life; the second - with the increasing importance in all the public, including the economic processes of the so-called human factor, which is based on individual leadership potentials, mobilized and organized in the interests of the system and the individual [2]. An indicator of the success of an innovative leader is not how influential and important the person is, nor the level of obedience and fear of his followers. Such a leader teaches people of responsibility at their level: to do their job well, to build relationships, to focus on the needs of the client, to study and apply new technologies. In addition, the real agent of the change has to see the ocean, and not the waves in it, he must think more systematically and widely. In order to focus on the challenges of today, one should understand the global causes, trends, systemic dynamics, understand the influence of their actions on the overall picture. You need to move away from the reaction regime, stop "extinguishing the fires", lifting your head, more to analyze and observe.

In 2010, for the first time in Ukraine, large-scale surveys were conducted from year to year (questionnaires, focus groups and semi-structured interviews) of the Ukrainian officials to take their views into account when identifying key groups of leadership competencies, training and development needs. The study of the needs took place using the "360 degrees" evaluation methodology. The essence of the "360 degrees" method is that the employee is evaluated by several people from his work environment: a leader, a colleague, a mentor, a project fellow, etc. As a rule, the number of the evaluators is not less than 4 people, which avoids the subjective factor in the evaluation of the employee by one person. When using this method, the professional and personal competencies necessary for effective work of an employee in a position are evaluated. This method of evaluation allows not only to evaluate the employees for compliance with the requirements of the organization, but also to identify their weaknesses. This information is the starting point for developing both a general strategy for training and development in the organization, as well as individual development plans for each individual employee. Often, the 360 degrees method, in addition to the circular evaluation of the business environment, also includes self-evaluation, which allows to evaluate the degree of compliance of the employee's opinion about himself with the opinion of other appraisers and, thus, give a more complete and useful feedback [3].

Today, the Leadership Development Program 2014 is being implemented in Ukraine, which provides the foundation for improving the human resources management, professionalization of the civil service, sustainable leadership development, and enhancing the efficiency of the public administration in general [3]. It is important that this program was developed on the basis of 
studying the training needs of the civil servants in Ukraine in accordance with the design of the key leadership competencies.

The purpose of this study was to compare the individual potentials of the innovative leaders, mobilized and organized in the interests of the system - the public administration and the business environment, and to understand what responses the representatives of the government agencies and business people are finding on the question "What is innovative leadership and its effective mechanisms in process management in conditions of the social change?"

Our qualitative research focuses on the depth of understanding of such a phenomenon as innovative leadership (IL) (and not the breadth as in quantitative/mass research) - that is, a detailed, in-depth research and understanding of the innovation leadership in its integrity and direct relationship with other phenomena, for example:

- IL in the public administration/ IL in the business environment;

- relationship (interaction);

- motivation to develop their competencies and leadership qualities.

Also, the research was conducted on some parameters of the innovation leadership, namely, the identity of the innovation leader (identification of the innovative leader), innovative leadership in the organization system (innovative leadership in the system - business and state executive bodies - based on the experience of the respondents), relationships (interaction) in a team/ organization (innovative leadership through the prism of relationships in a team/organization), the need to learn and develop leadership qualities (innovative leadership through the prism of motivation and development of competences "I-experience").

The period and geography of the research. The research was conducted by the author of the article from February 4, 2019 to March 17, 2019. Within the framework of the study 4 focus groups were organized -2 groups of the representatives of the state executive bodies and 2 groups of the business representatives.

The target cities were Kyiv and Mariupol.

The sample. We interviewed 48 respondents, of which 24 (12 men and 12 women, aged 23 to 57 years old, with experience in the government executive bodies from 2 to 15 years) represent state executive bodies, and 24 (16 men and 8 women aged 32 to 45 , with managerial experience in business from 5 to 14 years old) - representatives of various branches of the business.

The reliability of the research is ensured by the typicality of the participants.

The research was conducted in two stages.

$1^{\text {st }}$ stage. The identification of the personality of the innovation leader through the drawing of his portrait through personal traits and behaviour.

The method. The research is implemented using "qualitative methodology of the sociological research". The main advantage of using this approach is to identify new meanings that affect the behaviour. Therefore, the method of focus groups was chosen in order to clarify the data on the interpretation of the concept of innovation leadership 
in two different spheres of the governance - the public administration and the business environment - at the stage of the theoretical substantiation of some of the provisions of the author's dissertation study.

The assessing of the external personal traits and behaviour allowed to obtain the following results:

All the groups of the respondents noted the importance of a pleasant appearance, the attractiveness of an innovative leader, the importance of this person being perceived as a strong person who creatively approaches the tasks and processes in which he is located.

But the representatives of the state executive bodies stressed the need for a broad worldview, progressive views and a focus on the systemic self-development, while business representatives saw the established value system, the internal ethics code and high emotional intelligence as important for the business representatives (table 1).

As for behavioural characteristics, the ability to risk the practical implementation of all the new ideas seemed to be important for the representatives

Table 1

Portrait of the personal features of an innovative leader

\begin{tabular}{|l|l|}
\hline Representatives of the state executive bodies & \multicolumn{1}{|c|}{ Business representatives } \\
\hline Pleasant on appearance & Pleasant appearance \\
Courageous & Strong \\
Persistent & Open \\
Strong & Creative \\
Manful & Purposeful \\
Charismatic & Attitude to risk \\
Erudite & Formed value system \\
Wise & Internal ethics code \\
Educated & $\begin{array}{l}\text { Has a dream } \\
\text { Has a wide worldview }\end{array}$ \\
Has broad progressive views & Combines the "youth of the soul" \\
Focused on systematic self-development & with the professional experience \\
Organized & Professional \\
Has clear mission and vision (sees the way) & Constantly generates new ideas \\
Purposeful & Is able to adapt what works well \\
Specific & Is able to work with failure \\
Responsible & Is able to hold a shot \\
Think outside the box & Can listen \\
Strategist & Knowledge of psychology \\
Creative & Emotional intelligence \\
Other in looks & \\
Works non-standard & \\
Non-standard/non-template approaches/tools & \\
Do not stop there & \\
Desires change and embodies them & \\
\hline
\end{tabular}


of all the categories. For the representatives of the state executive bodies the characteristic "take responsibility for oneself" seemed necessary, while the business representatives consider the creation of value and a different view of the world as important (table 2).

Currently, the practice of transfer of the innovative business leaders in the public administration is common in the public administration in Ukraine. Therefore, the II stage of the research was related to the study of the competencies outside the system (transfer of the competencies, with the transfer of the business leaders to the state executive bodies). The participants have seen some factors that can lead to both success and the defeat of an innovative business leader in his transition to the public administration. Thus, the representatives of the state executive bodies noted that the resources in business and in the civil service are used for various purposes. In the business - to get the result, in the civil service - to be re-elected. Accordingly, for the leaders who are accustomed to focusing on the result may be difficult to reorient to more process work. The representatives of the state executive bodi- es also noted that in the business the leader has more levers of influence than in the public administration, accordingly, he will have to learn to achieve the goals by a much smaller number of instruments.

The business representatives said that since business has more freedom and money, the motivation for the transition of a business leader to the state executive authorities may not be understood. They also noticed the risk of the lack of a "drive", that, in fact, is the basis for innovation, due to the large bureaucratization of the civil service. According to the business leaders, the business representatives should hold higher positions in the government that give them greater freedom of action and promote innovation leadership.

Among the characteristics that contribute to the success of the business leaders in the public administration, the following were selected (see table 3).

Conversely, among the characteristics that may interfere with this success were named (see Table 4).

It is important to note that both the representatives of the state executive

Table 2

Portrait of the behavioural features of the innovation leader

\begin{tabular}{|l|l|}
\hline \multicolumn{1}{|c|}{$\begin{array}{c}\text { Representatives of the state executive } \\
\text { bodies }\end{array}$} & \multicolumn{1}{c|}{ Business representatives } \\
\hline $\begin{array}{l}\text { Leads } \\
\text { Takes the responsibility } \\
\text { Brings new ideas }\end{array}$ & $\begin{array}{l}\text { Tells about his failures } \\
\text { Trying to improve and change some- } \\
\text { thing } \\
\text { Not afraid to take risks } \\
\text { Inspires }\end{array}$ \\
Risks & $\begin{array}{l}\text { Creates value } \\
\text { Creates trust }\end{array}$ \\
Realizes in practice & $\begin{array}{l}\text { Works with tools that nobody used be- } \\
\text { fore } \\
\text { Makes decisions }\end{array}$ \\
\hline
\end{tabular}


Characteristics that contribute to the success of the business leaders in the public administration

\begin{tabular}{|l|l|}
\hline \multicolumn{1}{|c|}{$\begin{array}{l}\text { Representatives of the state executive } \\
\text { bodies }\end{array}$} & \multicolumn{1}{|c|}{ Business representatives } \\
\hline $\begin{array}{l}\text { A fresh look } \\
\text { Result orientation } \\
\text { Customer orientation } \\
\text { Targeting efficiency. }\end{array}$ & $\begin{array}{l}\text { Intelligence } \\
\text { Diplomacy } \\
\text { Good communication }\end{array}$ \\
$\begin{array}{l}\text { Experience in managing innovation } \\
\text { A clear vision of goals and objectives } \\
\text { Risk assessment and ability to predict }\end{array}$ & $\begin{array}{l}\text { Result orientation } \\
\text { Customer orientation }\end{array}$ \\
& $\begin{array}{l}\text { Ability to "sell" } \\
\text { Ability to face challenges } \\
\text { Ability to create commands }\end{array}$ \\
& Ability to manage people \\
Aability to distinguish known for the market \\
from the unknown \\
Ability to assess risks
\end{tabular}

Table 4

Characteristics that hinder the success of the business leaders in the public administration

\begin{tabular}{|l|l|}
\hline $\begin{array}{c}\text { Representatives of the } \\
\text { state executive bodies }\end{array}$ & \multicolumn{1}{c|}{ Business representatives } \\
\hline $\begin{array}{l}\text { - Failure to break the law } \\
\text { - Important attention to } \\
\text { the social aspect }\end{array}$ & $\begin{array}{l}\text { - Another (slower) pace of work of the state executive author- } \\
\text { ities }\end{array}$ \\
- Not everything can be & $\begin{array}{l}\text { Business procedures are simpler than the civil service pro- } \\
\text { cedures }\end{array}$ \\
$\begin{array}{l}\text { estimated through eco- } \\
\text { nomic effect }\end{array}$ & $\begin{array}{l}\text { - Public service has more operational tasks than business } \\
\text { - In the system of civil service a person can not work indepen- } \\
\text { dently } \\
\text { - It is difficult to create a team within the structure of the state } \\
\text { executive bodies } \\
\text { - The work of the state executive bodies depends on the po- } \\
\text { litical cycles }\end{array}$ \\
\hline
\end{tabular}

bodies and the business representatives have noted the presence of a mission in their organizations, but the key values of these categories are very different. The key values that are prevailing at the state service are to do more at a lower cost, to create a good working atmosphere and treat each other with respect, to seek new approaches to work. The business representatives highlighted honesty, a practical approach, aspiration for growth and learning.
It is known that the innovation corporate culture should be the reverse side of the personal innovation leadership. Here we also see the difference: in the bodies of the state executive power the corporate culture is characterized as authoritarian-democratic, and in business - as a democratic one.

Among the competencies of the innovation leader are called the following: 
- change management;

- human management;

- orientation to the result;

- business capability/grip.

Ranking the need for competencies of the innovation leadership these two categories of managers showed the following:

This ranking showed the greatest similarity between the representatives of the both groups. We see that the representatives of both the state executive authorities and the business have identified the most important competence in managing change and the second in terms of meaning - human management (table 5).

The leadership is a phenomenon that requires constant work with one's own personality. So, the next question we tried to determine, what exactly can become the factors of motivation for the further development of the in- novative leadership. As we see, the representatives of the state executive bodies unanimously called the only motivational factor, while the business representatives have a whole range of them (table 6).

As we anticipate the need to introduce innovative leadership development mechanisms in the public administration, it was also very important to find out which topics are considered necessary for this development by the representatives of the both categories. (see table 7).

\section{Conclusions.}

The conducted study allowed to obtain the following results:

1. The innovative leader is always creative. He is charismatic. He has a high emotional intelligence. He is not afraid to do something in a new way. He is always respected. He is demanding.

Table 5

Vision of the need for competencies of the innovation leadership

\begin{tabular}{|c|c|}
\hline $\begin{array}{c}\text { Representatives of the state executive } \\
\text { bodies }\end{array}$ & Business representatives \\
\hline $\begin{array}{l}\text { - First position in ranking - the most impor- } \\
\text { tant - change management } \\
\text { - Second position - the human manage- } \\
\text { ment } \\
\text { - Third position - the business capability/ } \\
\text { grip } \\
\text { - Fourth position - focus on the result }\end{array}$ & $\begin{array}{l}\text { - First position in ranking - the most impor- } \\
\text { tant - change management } \\
\text { - Second position - the human manage- } \\
\text { ment } \\
\text { - Third position - focus on the result } \\
\text { - Fourth position - the business capability/ } \\
\text { grip }\end{array}$ \\
\hline
\end{tabular}

Table 6

Factors of motivation for the further development of the innovation leadership

\begin{tabular}{|l|l|}
\hline $\begin{array}{c}\text { Representatives of the state } \\
\text { executive bodies }\end{array}$ & \multicolumn{1}{c|}{ Business representatives } \\
\hline $\begin{array}{l}\text { - Desire to change the current } \\
\text { situation, but has lack of know- } \\
\text { ledge }\end{array}$ & $\begin{array}{l}\text { 1. Understanding that all the changes begin with oneself. } \\
\text { Further: }\end{array}$ \\
& $\begin{array}{l}\text { - Readiness to share their own experiences } \\
\text { - Desire to change the situation that is } \\
\text { - Desire to move on } \\
\text { - Availability of the necessary qualities for such learning }\end{array}$ \\
\hline
\end{tabular}


Priorities of the development of the innovative leadership in the public administration

\begin{tabular}{|l|l|}
\hline \multicolumn{1}{|c|}{$\begin{array}{c}\text { Representatives of the state executive } \\
\text { bodies }\end{array}$} & Business representatives \\
\hline - Strategic vision, strategic management & - Change management \\
- Use of modern human and process & - Innovation and innovativeness as a phe- \\
management technologies & nomenon and its political revelations \\
- Skills of creative thinking & Psychology of the team \\
\hline
\end{tabular}

2. The need for innovation leadership development was recognized as one of the key competencies for executives both in the state executive bodies and in the business.

3. The transfer of the innovative business leaders to the bodies of higher executive power can be very successful, subject to certain requirements.

4. The focus group participants had the hardest (more complicated) explanation of the following points related to:

- the difference in the concepts of "leader" and "innovative leader", often these concepts were identified, since the notion of the "leader" for many participants already included the concept of "innovativeness";

- the motivation for the transition of the business leaders to the state executive bodies - it has not always been clear to the representatives of the both groups.

\section{Main results of the research:}

Most participants in the research understand that the development of the innovation leadership is a necessary component for further career growth both in the bodies of higher executive power and in the business environment.

Almost all can also name personality features and behavioural patterns that contribute to success in the development of the innovative leadership.

More difficult was the question of what exactly the innovative leader differs from the leader.

A certain proportion of the respondents hesitated among the options that an innovative leader is a leader who is constantly generating new ideas and new ways to solve complex situations, while the other part considered the innovative leadership successful implementation of these decisions and ideas in practice as their own leader and the ability of an innovative leader to inspire on this team.

Despite the fact that all the participants of the discussion agreed that the transfer of the business leaders to the higher executive bodies could be very successful, some of them expressed doubts about their ability to work in the higher executive bodies for a long time due to the difference in the system values and peculiarities of the organizational culture in the business and in the civil service. Such respondents noted that the increased bureaucracy in the higher executive bodies does not promote flexibility and result orientation, which are the main requirements for the leaders in the business environment. But some respondents do not exclude that the business leaders can be successful in higher positions where 
they will have more freedom and authority for them, and in terms of understanding their political cycles in the country.

The conducted research allows to highlight the features of the innovative leadership as a form of professional evolution in the public administration through the definition and analysis of the behavioural and personal components, as well as to establish regularities to the formation of the innovative leadership in the field of the public administration and in the business environment.

\section{REFERENCES}

1. Tkachova O. (2013). Efektyvnist derzhavnoho upravlinnia: poniattia ta pidkhody do otsiniuvannia [Efficiency of state administration: concept and evaluation approaches]. Visnyk Natsionalnoi akademii derzhavnoho upravlinnia pry Prezydentovi Ukrainy - Bulletin of the National Academy of Public Administration under the President of Ukraine, 2, 30-37 [in Ukrainian].

2. Pospielova T. V. (2011). Mekhanizmy derzhavnoho upravlinnia liudskym rozoytkom v Ukraini: monohrafiia [Peo- ple Development Mechanisms in Public Administration in Ukraine: monograph]. Donetsk: Nord-Pres [in Ukrainian].

3. Bizo L., Ibrahimova I., Kikot O., Baran Ye., Fedoriv T. (2012). Rozvytok liderstva [Leadership Development]. Proekt: "Reforma upravlinnia personalom na derzhavnii sluzhbi v Ukraini" Project "HR Public Administration Reform in Ukraine”. I. Ibrahimova (Ed.) [in Ukrainian].

\section{СПИСОК ВИКОРИСТАНИХ ДЖЕРЕЛ}

1. Ткачова О. Ефективність державного управління: поняття та підходи до оцінювання / О. Ткачова // Вісн. Нац. акад. держ. упр. при Президентові України. 2013. № 2. C. 30-37.

2. Поспєлова T. В. Механізми державного управління людським розвитком в Україні: монографія / Т. В. Поспєлова. Донецьк: Норд-Прес, 2011. $350 \mathrm{c}$

3. Розвиток лідерства / Л. Бізо, І. Ібрагімова, О. Кікоть, Є. Барань, Т. Федорів ; за заг. ред. І. Ібрагімової. К. : Проект "Реформа управління персоналом на державній службі в Українi”, 2012. 400 c. 